\title{
Understanding Digital Trends in Marketing Agribusiness Products: Critical Analysis of International Publications
}

\author{
Adya Hermawati \\ Universitas Widyagama Malang, Magister Management department, Indonesia \\ Corresponding author email: wati_wati38@yahoo.co.id \\ Sylvia Fettry \\ Universitas Katolik Parahyangan Accounting Department, Faculty of Economics Bandung, Indonesia \\ Email: sylvia.fettry@unpar.ac.id \\ Suhermin \\ Management Depaetment, Sekolah Tinggi Ilmu Ekonomi Indonesia (STIESIA) Surabaya, Indonesia \\ Email: suhermin@stiesia.ac.id
}

\begin{abstract}
This review study aims to gain an in-depth understanding of the extent to which digital trends in marketing agribusiness products are under the needs of farmers who live and farm in today's digital era. We chose to analyze national and international publications to understand the objectives of the study quickly. So our step is to look for study evidence data through electronic searches on Google Scholar-based data published between 2010 and 2021 to get the latest data. Furthermore, our data analysis involves data coding, evaluation, and in-depth interpretation to obtain valid and reliable findings as expected in the study findings. Because this study was conducted during the pandemic, we tried to get secondary data and follow descriptive qualitative data experts' directions. As a result, we can conclude another way that digital marketing in marketing agricultural products is a technique that is becoming trendy in many places. The digital trend is chosen by many people because of its easy and cheap principles so that both farmers and buyers will be lucky because marketing operations have been trimmed. Thus the results of this study are helpful for many parties.

Keywords---analysis study, digital trend, marketing agribusiness products.
\end{abstract}

\section{Introduction}

There is great concern regarding farmers' fate and living conditions in Indonesia from the past until now when the world continues to change (Mariyono, 2019; Wang et al., 2020). In this case, the farmers or agricultural product entrepreneurs who cannot keep up with the times will be left behind. The main problem is the low selling price at the farm level caused by the long distribution chain and farmers' dependence on intermediaries. Even under certain conditions, farmers are forced to sell before the harvest arrives. The fact is that currently, not many farmers use information technology to support marketing activities in Indonesia (Lestari \& Premono, 2019). Whereas farmers also live and work farming in the era of internet technology and social media, which are rooted in Indonesian society's social life. If they had the access and skills to use this digital technology, their fate would, of course, be more advanced and would compete with farmers and other entrepreneurs in the world (Janc et al., 2019; Klerkx et al., 2019). Appels et al., (2018) predict that around 55.56\% of farmers' agricultural products have been purchased by middlemen before harvesting. Farmers who do not know the sales information directly hand over their harvest to the middlemen, so that if the harvest is good, many farmers will suffer losses. Most of the farmers in Wonotulus Village are old and have primary and junior high school education. The younger generation prefers to migrate to cities or choose professions outside of agriculture. The goal of community service is to introduce digital marketing to 
millennial farmers in marketing agricultural products. The marketing chain for agricultural products can be cut by connecting farmers directly to consumers. This can be done using online marketing and digital media on the internet to reach consumers. Deichmann et al. (2016) doubt that agricultural products' marketing will reach rural trade and change the way agriculture is used in developing countries? World Bank estimates have some point where introducing this material is needed to provide knowledge to farmers to provide information to break the marketing chain.

For marketing agricultural products, the Kingsnorth (2019) suggests that farmers now have to take advantage of digital tools for marketing. Because this digital marketing method is a proven approach, they must help farmers develop products widely in today's world; knowledge of online marketing is needed. The government and the private sector have established many agricultural marketplaces to help farmers in buying and selling. However, the implementation of digital marketing, especially for farmers in rural areas, still takes a long time and requires adequate infrastructure availability. Implementation barriers can be technical and non-technical, requiring full cooperation between the government, e-call developers, and e-commerce companies (Oreku et al., 2013; Brenes et al., 2014; Capmany et al., 2000).

\section{The economic sector is evenly distributed}

Bali must not close its eyes, betting on only one sector, namely tourism (Introna et al., 2014). So it takes bold, tactical, and systematic steps for policymakers to move the wheels of the economy. To maintain economic stability in Bali, the Bali Province Bank Indonesia responded aggressively to the Balinese economy. Because Bali relies heavily on food from outside, for example, the 2019 Rice Trade Distribution Pattern survey showed 52.41 percent of rice supplied from East Java, Central Java, and Java (Gil et al., 2000; Puchalsky et al., 2018; Ariani, 2015). Tabanan Regency is known as the icon of Bali's rice barn. The economy of Bali is one-sided. Seeming very unbalanced, we feel Bal Indonesia's economy is unjust. Breakthroughs need to be made to build an economy that involves all sectors, working hand in hand from all elements, both government, private, and community on the Island of the Island. (Yuendini et al., 2019). These two sectors have contributed to maintaining the ecosystem that controls the level of public consumption. Building optimism is essential, but words are not enough to take advantage of digitization.

Bali Province Bank Indonesia (BI) has been aggressively responding to the Balinese economy's systematic movement. Farmers are assisted in being more literate with digital marketing systems or the digital world, hoping that farmers will make transactions easier and maintain the quality of the products they produce (Wulandari \& Parameswara, 2019). BI's steps to encourage farmers to compete in this digital era have to be fully supported across sectors. Most importantly, the implementation is carried out, or according to the harvest season, such as the durian season, mango season, coffee season. This year's crop yields have increased tremendously. A land area of 89 acres can produce more than 100 quintals $(1000 \mathrm{~kg})$ wet. Compared to the previous year, most produce 50 quintals of wet. On average, according to farmers in Dapdaputih Village, Buleleng, the coffee harvest this year has increased compared to last year. The goal is to bring farmers or producers closer to consumers (Dewi \& Sutrisna, 2014).

Assisting farmers is very important, starting from training, providing capital injections for marketing methods, to taking advantage of product digitization (Sterne, 2017; Buhalis et al., 2019). Other efforts need to be initiated by other parties or stakeholders. Business people should change their mindset to consider online business activities more. Gradually, the informal sector and traders in traditional markets will also shift towards digital technology in the e-Commerce industry, writes Suryadi. The e-commerce industry becomes the backbone for trading activities in the real sector, and it can stay alive, she says. The Bali Provincial Government's move to support the cooperation market program initiated by the Bali Government also deserves appreciation, she adds.

Strategy to marketing the agricultural sector is an integral part that cannot be separated from the economic system. Its labor-intensive nature and high social capital allow farmers to absorb a lot of labor (DeLind, 2013; Goodman et al., 2012). When the monetary crisis occurred in 1998, when other sectors experienced strong layoffs, the agricultural sector remained stable absorbing labor. The welfare of farmers has not accompanied the increase in foreign exchange. However, data from the World Bank states that $40 \%$ of agricultural workers in rural areas can escape poverty by working in the rural agricultural sector, boosting the rural agricultural sector's capacity. The agricultural sector has a strategic role in obtaining foreign exchange from exports of agricultural products. It provides employment and is the sector that absorbs the most workforce. It has a role in providing public food as an effective effort to prevent its spread "remains in the available food house." It is also the defense sector, which is essential in winning the war against Covid-19. It is the part of Indonesia's economic system that provides employment (Naryono, 2020; Putra et al., 2020). 
Succeed in agricultural marketing; youth must be involved in developing the agricultural or rural sector and become a threat if there are no jobs and income sources (Sumberg et al., 2014; Adesugba \& Mavrotas, 2016). Young farmers can provide new energy, enthusiasm, and innovation. In recent years, only about $11 \%$ of young people are willing to work in the agricultural sector. Neglecting youth involvement is akin to missing an opportunity to "rebrand" the Agriculture sector. Rebranding is needed to answer the needs of more modern and competitive agriculture in the era of globalization (Ridha \& Wahyu, 2017). The next generation of young people will be the generation who are skilled in technology. The digitization of agriculture is an attractive form for the younger generation to see the agricultural sector as a career opportunity, no longer something that the older generation can only do. This is an opportunity for young people to see agriculture as something that can engage them, not just something dirty with mud (David, 2017; Slamet et al., 2016).

Currently, there seems to be a tendency for young people to return to agriculture. Firman et al. (2019) describe Indonesia's success; its dairy farm family was immense. This is the time for young people to think outside the box. Because if it is easy for children to be deployed in agriculture, indeed they are the digital generation ready to merge with the marketing of agricultural products. This trend of youth returning to farming in Indonesia will change agriculture's face into a more prestigious sector today and in the future (Bahua, 2016). It is very optimistic that increased youth involvement in the agricultural industry will impact the welfare of farmer households and increase food availability for all people. In the conditions of Covid-19, if our young generation is raised to develop the agricultural sector, then Indonesian people will be calmer, stay at home with food availability and reduce poverty levels in rural areas (Reardon et al., 1999; Ziggers \& Trienekens, 1999: Sanim, 2016).

What is the role of the government in maximizing agriculture in the integrity of digital technology? The Ministry of Agriculture invites the millennial generation or the younger generation to participate in the agribusiness sector (Rachmawati \& Gunawan, 2020). This makes Indonesia the world's food barn. Every year, Indonesia loses about 2\% of farming households due to switching to other sectors outside the agricultural sector. This is a misguided development sequence in which state planning as a model for young people has lost its direction. The number of farmers who choose to move to work in other sectors is more than the number of young people who decide to pursue agricultural business (Arvianti et al., 2019). If this continues, then the government's target to make Indonesia the world's food barn by 2045 could be just wishful thinking (Harjadi, 2016).

The findings of Grebitus et al. (2017) have confirmed that there is a close relationship between consumer behavior and the success of agriculture in the country. One way to overcome the decline in the number of farmers in the country is to actively invite the millennial generation to participate in the agricultural sector. The millennial generation is synonymous with the digital age (Printezis \& Grebitus, 2020). They can play an active role in maintaining the farm industry by taking advantage of business opportunities combined with the latest technology. Marketers in today's world are constantly flooded with new ideas, new platforms to promote their business, and new technologies to take advantage of. On the other hand, they will quickly keep up with changes, which can overwhelm marketers (Carzedda et al., 2020).

For this, correspondence innovation or digital use can assume participation, and correspondence innovation helps agriculture develop and create associations with agricultural products' buyers. They strengthen the continuity of the hierarchy and help individual farmers to learn. Advances such as the web, online media, and maintaining good relationships with clients and board frameworks significantly influence how organizations talk to their intended clients. This is the point that the younger generation enters with technological enthusiasm. Then what is on the minds of farmers about digitizing millennial account marketing? Today's young population is significant for millennial age and is the shoppers who drive change towards advancing new correspondence (Smith, 2011).

Young buyers may decide to get an advertising promotion through a portable display or use a multipurpose gaming gadget to connect to a business site (Juswadi et al., 2020). Likewise, publications on Facebook are also known as organizations that continue to advertise their products through web-based media. Traditional media such as magazines, newspapers, TV compete with computerized media such as the web, visit administration, online media, client-generated content such as web journals and YouTube. Therefore, all performance media types are required to introduce new developments to remain valid for the event. Assuming high buyers and fast use of computerized gadgets, today's advertisers will face another test intended for this and use the information to make solid connections (Coderoni \& Perito, 2021).

\section{Method}

To get an in-depth analysis and understanding of digital trends in farmers' crops' marketing, we chose to systematically review dozens of model publications and marketing strategies for digital technology. So our way is to 
search for evidence of studies on electronic publications on Google Scholar-based digital print data between 2010 and 2021 to get new data. Then we analyzed the data with a coding system, evaluated and interpreted in-depth data to obtain findings based on validity and reliability as desired. Because this study was carried out during the pandemic, secondary data is the best solution. It follows the directions of descriptive qualitative study experts such as Silverman, (2020) and the data review of the Méndez-Lazarte, (2019) with his analysis of the dynamic framework in early agribusiness and technology.

\section{Result}

Our results section will present the core findings of this electronic search with the primary objective of understanding in-depth digital trends in marketing agribusiness products through a systematic review of internationally published articles. Meanwhile, the discussion of findings will be presented in the next section.

The first understanding finding is from Bowen \& Morris (2019). They examined automatic partitioning and its implications for agribusiness and business. Because it is estimated that $84 \%$ of the total land area in Wales is used for horticulture is essential. The food and cultivation area is an integral part of the Welsh economy that is an outstanding provincial state with 738 breeders and 107 food SMEs in Wales. Powerless availability has driven limited PC capabilities and complex innovation options to a low level. The Welsh government had to tackle this problem to limit the channels of talented individuals' minds to metropolitan areas, often outside Wales. The test was used to study information from 738 Farmers and 107 Food SMEs in Wales, with 19 subsequent semi-organized meetings. The findings recommend that the province remains in a difficult position due to powerless networks, an issue the Welsh Government must address. Likewise, Rambe \& Khaola (2021) results with a study of the impact of innovation on the power of agribusiness, which we compete with, mediated by technology and agribusiness productivity.

Bowen \& Morris (2019) findings regarding computerized partitioning and its implications for agribusiness and business are essential. It is estimated that $84 \%$ of the total land area in Wales is used for horticulture. The food and cultivation area represents an integral part of the Welsh economy that is an outstanding provincial state with 738 breeders and 107 food SMEs in Wales. Powerless availability has driven the PC's limited capabilities and a complex selection of innovations at a low level. The Welsh government had to tackle this problem to limit the channels of talented individuals' minds to metropolitan areas, often outside Wales. The test was used to study information from 738 Farmers and 107 Food SMEs in Wales, with 19 subsequent semi-organized meetings. The findings recommend that the province remains in a difficult place due to powerless networks, an issue the Welsh Government must address.

Likewise, the study of Birner et al. (2021) asked who was driving further transformation in horticulture, an analysis of patterns of business practices, business actors, and their problems. The discourse of small computerized agriculture-arrived at favorable conditions for the accelerated economic change of rural communities. Evidence of the study and guided by the funding hypothesis, this study proves that digital agribusiness is driven by the private sector, including running input businesses and programming businesses worldwide and new companies that recognize the benefits of agriculture. Even though there are concerns that good horticulture will increase the market power of large agribusiness enterprises and increase automatic partitioning, the mix of new entrants and broader community activities could help accelerate computerized inventories of rural digital innovations, monitor the dangers of market fixation, and curb computerized farming opportunities for all.

Molotkova et al. (2019) studied the improving Russian agribusiness seriousness inside the mechanical change structure. In International Scientific Conference "Advanced Transformation of the Economy. In the Tambov area, as in the agro-mechanical locale, special consideration is paid to farming improvement. A promising territory for advancement in the rural area is the turn of events and creative, innovative arrangements. In the locale, work is in progress to open the first in the district Technopark in the field of data innovation "Mielta" The reason for Technoparks is to create imaginative business structures nearby.

Tsekouropoulos et al. (2013) showcasing and digital functions in Greek rural agribusiness through classification. Advertising is considered as a center action of an undertaking. Advertising is considered as a center action of a venture. Expanding the number of agribusinesses is looking to the internet as a promotion, executives, administration, and coordination apparatus. This paper intends to arrange the rustic ventures' corporate sites, utilizing a bunch examination, in bunches as indicated by their advertising and computerized capacities in their sites.

Jouanjean (2019) studied digital opportunities for trade in the agriculture and food sectors. How are new freedoms to make and share data molding the farming and food framework's computerized change and possibly encouraging its revamping? This report centers around cross-line exchange angles along the worldwide farming and food esteem chain and sees how changes achieved by advanced advances can impact who partakes in the worth 
chain, where worth added is made, and how worth is dispersed between entertainers in the chain. Nonetheless, it is not just changed in the farming and food area from advanced innovations that are important, yet the computerized change of different entertainers in the worldwide worth chain (VGC, for example, support administrations, coordinates, and governments. Advanced innovations present a possibility to decrease exchange and exchange costs, including identifying and arranging an arrangement, demonstrating consistency with guidelines, and conveying items across borders rapidly and effectively.

Likewise, the study of Irungu et al. (2015) under the theme of advances in data and correspondence that attract youth into fruitful horticulture in Kenya is accurate. The fact is that youth love innovation, effectiveness, and development and obliges the pioneer's will. The presence of YouTube, Twitter, and WhatsApp should be expanded and generally supported among young people. The most frequently used tools are MS Office and the accounting page for record-keeping. Voicemail and SMS help the convenience of reaching market costs, arriving at customers, sharing data making and exchanging money. The digital-savvy youth will work in earnest, skilled, and rewarding agriculture, delivering a wide variety of marked goods for a niche market. Youth change local area use and acceptance to technological ways and influence the local area's monetary status. PDA innovations will change the acceptance and use of Icons and will transform local acceptance of the innovation.

Here Irungu et al. (2015) successfully studied the increase in agribusiness's advanced stage to import substitute foodstuffs. This paper explores the structure for the progressive agricultural stage organization as a composition comprising a unified financial framework to advance Russia's computerized improvement. The investigation plans to differentiate the integrated method of progress from the motorized stage to expand agricultural makers' financial capabilities and ensure foodstuff imports. This paper provides the rationale for the continued shift from horticultural creation. The unified motorized stage to the Russian agricultural economy. Digitalization measuring both at the substance level of the constituents of the Russian Federation and the emerging countries.

Tsekouropoulos et al. (2013) also examined digital tools to market multi-criteria products from small agricultural business web networks in Greece. The onslaught of new advances combined with a significant cost to run the power shop business looking for new deal strategies. Organizational applications and ICT (Information and Communication Technology) can help achieve online business goals. In Greece, many companies in the agro-food and beverage sector are already on the internet. This paper discusses web-based businesses' acceptance on sites that help online practice business in the agro-food and drink area. Therefore, this paper intends to distinguish and assess the quality of their subjective and quantitative substances, rank them according to the six attributes/substance models that use a multi-criteria strategy for PROMETHEE II, and organize them in a comparative appropriation pool. This study's findings reveal the speed with which web-based businesses are accepted in the region and can be used as an essential model for site planners advancing web-based business practice within the broader food and beverage space.

Next, Machfud \& Kartiwi (2013) examine how online businesses have stolen small Indonesian agribusinesses' attention. Small companies have reconsidered the preferred cycle model of advancing through the use of digital tools. The study of web-based businesses' selection by private companies in non-industrialized countries received significant attention in the previous decade. This paper discusses and proposes a Rogers model that incorporates all development choice cycle components to gain a superior understanding of selection interactions. This highlights Indonesia's small agribusiness, where there is still little planning for internet business design.

While the study by Johnson et al. (2011) looked at the benefits of expanded Broadband for Missouri agricultural and agribusiness businesses, the Missouri province metropolitan network opportunities are vast and growing. Broadband access allows farmers to reduce data sources and increase the quality and quantity of goods. Strategy producers and residents should pay attention to the advantages of broadband access for themselves, their children, and their organizations. The relationship between private, government and not-for-profit areas should be encouraged. State and environmental governments should audit existing resolutions and guidelines to identify and impose barriers to rural forms of broadband. The authors suggest that regulatory producers return to the series of country experiences of empowering and empowering different basic frameworks in provincial areas. The report concludes with proposals for the fate of the state's web access foundation and broadband administration progress in the province of Missouri. "Rural Internet in Missouri"

Likewise, Capello et al. (2016) examined how constant check administration relies on modern networks to oversee the excellent coordination of incoming and outgoing data on agricultural business-related matters. Mechanical Internet of Things (IIoT) innovation can generate added value for coordination, especially in the agribusiness sector. See Box Ltd has built an IIoT-based innovation ready to fill any holes in the area. The organization provides constant coordination of inventive observing assistance to traders. Such aid will empower the following items from the end shopper back to the field. 
Our latest findings raise Vassiliadou et al. (2011) namely social media use among students of agricultural technology and its role in promoting agribusiness. This paper examines the relationship between students and the web-based media stage. It presents the utilization of online media by students aged 19-31 years. It analyzes how long they spend "hanging out" through online media and why they use it. Understanding accepts that agribusiness can benefit by "abusing" the web-based media stage. This paper examines what broadens students' acceptance that online media can help organizations work with individuals' relationships.

\section{Discussion}

A deeper understanding of agribusiness products' marketing in the modern era involving technology is a promising trend that is increasingly down to earth. From several scientific evidence from previous studies, it has provided vital support to add new understanding. The majority of the publications we review confirm that more and more experts prove that technology is very relevant to agriculture, especially in the marketing of agricultural products. In this case, they suggest the digitization of farmers because the principles of utility and effectiveness help accelerate the marketing work of farm products to be more easily accessible to many consumers from all corners of the country to outside the country. Compared to traditional marketing methods and strategies, the digital process is the cheapest and easiest option because the average potential consumer now has access to smartphones and connections that are getting easier and cheaper. Few experts suggest that digitization must start from the planning stage, implementing and marketing the results if they want to get more significant benefits and benefits. Astutiningsih \& Sari (2017) with a marketplace-based study of e-commerce on effectively distributing farmer products' marketing, was proof. Likewise, the results of Utami (2020) study (which examines the introduction of digital-based marketing, marketing of farmers' harvests in rural villages that have become millennial communities.

Furthermore, when viewed in terms of customer or consumer satisfaction, digital technology marketing is several agribusiness sales activities whose primary purpose is to provide fast and inexpensive services so that the cost can be reduced for consumer satisfaction of farmers' products. Thus, the goods follow consumers' demands and choices, which are remotely impossible to achieve without a digital application connected to the internet. Hadi \& Khairi (2020) findings regarding marketing strategies in the era of website trends in Indonesia's farmer networks were relevant.

The method of marketing agricultural products with technology is a business activity. This way, farmers can simultaneously sell their products to previously needed an agent as an intermediary between them and potential customers. Furthermore, the desire for agricultural commodities is increasingly in line with consumers' needs and wants, where they can interact directly. With the hope, the digital way is the best system and strategy. At this time, potential consumers will be satisfied with getting the best commodities without a third party. Digital marketing methods can include moving products from farmers directly to the consumer of today's digital world. Tak (2021) also reviewed similar marketing education results for agricultural products on the internet with the E-Commerce application.

Apart from the advantages and advantages of digital applications in marketing agricultural products, digital applications in the farming business also have many disadvantages. This is because the farmers are mostly the older generation, where they do not have sufficient competence in using this very high-tech digital application. Following the recognition of experts from the publications we visited, they provide very significant reasons to believe that, among other things, if farmers in rural areas use the application, they should look for experts who can help use digital applications.

Other reasons and weaknesses, for example, are that farmers have little time to adapt and have a low level of learning technology. Because they become influential farmers with digital, they must have high passion. Other admissions include farmers that it is challenging to apply digital without a basic understanding of technology. The author himself dares to guarantee that even though the farmers are wealthy, it is tough to use digital tools to market their crops. So it is very likely for farmers that this model will be useless what digital applications exist. Evidence of this truth can be seen in a study by Purnomo (2020) to strengthen agricultural, human resources with training and guidance on practical technology.

\section{Conclusion}

Finally, we can conclude that the study aims to understand digital trends in farming, especially the application of technology to market agricultural products in the era of technology, which we have done with very relevant and valid results. It cannot be denied that digital integration in farming is the marketing of agricultural products that have 
become increasingly widespread until it has entered the village of agricultural pockets. With their concrete evidence, several publications have voiced how digital sophistication can benefit both business people and consumers because, with their technology, they can be more productive. Hopefully, this study's results will help many academics, researchers, farmers, and policymakers.

\section{Acknowledgments}

We authors would like to thank to all support and encouragement from colleagues who have purposely provide us with valuable resources in the begining until we finish the project. Similarly the funding support from university so that we can complete this project entitled Understanding Digital Trends Marketing Agribusiness products through Critical Analysis of Internasional Publication.

\section{References}

Adesugba, M. A., \& Mavrotas, G. (2016). Delving deeper into the agricultural transformation and youth employment nexus: The Nigerian case (Vol. 31). Intl Food Policy Res Inst.

Appels, R., Eversole, K., Stein, N., Feuillet, C., Keller, B., Rogers, J., Pozniak, C. J., Choulet, F., Distelfeld, A., \& Poland, J. (2018). Shifting the limits in wheat research and breeding using a fully annotated reference genome. Science, 361(6403).

Ariani, M. (2015). Dinamika Konsumsi Beras, Jagung dan Kedelai Mendukung Swasembada Pangan. Badan Penelitian Dan Pengembangan Pertanian.

Arvianti, E. Y., Masyhuri, M., Waluyati, L. R., \& Darwanto, D. H. (2019). Gambaran Krisis Petani Muda Indonesia. Agriekonomika, 8(2), 168-180.

Astutiningsih, S. E., \& Sari, C. M. (2017). Pemberdayaan Kelompok Agroindustri Dalam Upaya Mempercepat Pertumbuhan Ekonomi Jawa Timur. Jurnal Ilmu Ekonomi Terapan, 2(1).

Brenes, E. R., Montoya, D., \& Ciravegna, L. (2014). Differentiation strategies in emerging markets: The case of Latin American agribusinesses. Journal of Business Research,67(5), 847-855. https://doi.org/10.1016/j.jbusres.2013.07.003

Bahua, M. I. (2016). Kinerja Penyuluh Pertanian. Deepublish.

Birner, R., Daum, T., \& Pray, C. (2021). Who drives the digital revolution in agriculture? A review of supply-side trends, players and challenges. Applied Economic Perspectives and Policy.

Bowen, R., \& Morris, W. (2019). The digital divide: Implications for agribusiness and entrepreneurship. Lessons from Wales. Journal of Rural Studies, 72, 75-84.

Buhalis, D., Harwood, T., Bogicevic, V., Viglia, G., Beldona, S., \& Hofacker, C. (2019). Technological disruptions in services: Lessons from tourism and hospitality. Journal of Service Management.

Capello, F., Toja, M., \& Trapani, N. (2016). A real-time monitoring service based on industrial internet of things to manage agrifood logistics. 6th International Conference on Information Systems, Logistics and Supply Chain, 18.

Capmany, C., Hooker, N. H., Ozuna Jr, T., \& van Tilburg, A. A. D. (2000). ISO 9000-A marketing tool for US agribusiness. The International Food and Agribusiness Management Review, 3(1), 41-53. https://doi.org/10.1016/S1096-7508(00)00027-6

Carzedda, M., Nassivera, F., Marangon, F., Troiano, S., Iseppi, L., \& Bassi, I. (2020). Urban Food Security and Strategic Planning: Involving Millennials in Urban Agriculture. International symposium: New Metropolitan Perspectives, 91-100.

Coderoni, S., \& Perito, M. A. (2021). Approaches for reducing wastes in the agricultural sector. An analysis of Millennials' willingness to buy food with upcycled ingredients. Waste Management, 126, 283-290.

David, W. (2017). Organic agriculture in Indonesia: Challenges and opportunities. Organic Agriculture, 7(3), 329338.

Deichmann, U., Goyal, A., \& Mishra, D. (2016). Will digital technologies transform agriculture in developing countries? The World Bank.

DeLind, L. B. (2013). 11 Considerably More than Vegetables, a Lot Less Than Community: The Dilemma of Community Supported Agriculture. In Fighting for the Farm (pp. 192-206). University of Pennsylvania Press.

Dewi, N. L. S., \& Sutrisna, I. K. (2014). Pengaruh komponen indeks pembangunan manusia terhadap pertumbuhan ekonomi Provinsi Bali. E-Jurnal Ekonomi Pembangunan Universitas Udayana, 3(3), 44443. 
Firman, A., Paturochman, M., Budimulyati, S. L., Hadiana, M. H., Tasripin, D., Suwartapradja, O. S., \& Munandar, M. (2019). Succession decisions in Indonesia family dairy farm business. Livestock Research and Rural Development, 31(9).

Goodman, D., DuPuis, E. M., \& Goodman, M. K. (2012). Alternative food networks: Knowledge, practice, and politics.

Gil, J. M., Gracia, A., \& Sanchez, M. (2000). Market segmentation and willingness to pay for organic products in Spain. The International Food and Agribusiness Management Review, 3(2), 207-226. https://doi.org/10.1016/S1096-7508(01)00040-4

Grebitus, C., Printezis, I., \& Printezis, A. (2017). Relationship between consumer behavior and success of urban agriculture. Ecological Economics, 136, 189-200.

Hadi, A. S., \& Khairi, A. (2020). Pemilihan Strategi Pemasaran di Era Digital pada Kelompok Ibu PKK Desa Gadingharjo. Dinamisia: Jurnal Pengabdian Kepada Masyarakat, 4(1), 127-132.

Harjadi, M. M. S. S. (2016). Peranan ilmu hortikultura bagi pembangunan negara dan budaya bangsa. Peningkatan Produksi, Manfaat Sustainability Biodiversitas Tanaman Indonesia Volume II, 185.

Introna, M., Lucchini, G., Dander, E., Galimberti, S., Rovelli, A., Balduzzi, A., Longoni, D., Pavan, F., Masciocchi, F., \& Algarotti, A. (2014). Treatment of graft versus host disease with mesenchymal stromal cells: A phase I study on 40 adult and pediatric patients. Biology of Blood and Marrow Transplantation, 20(3), 375-381.

Irungu, K. R. G., Mbugua, D., \& Muia, J. (2015). Information and communication technologies (ICTs) attract youth into profitable agriculture in Kenya. East African Agricultural and Forestry Journal, 81(1), 24-33.

Janc, K., Czapiewski, K., \& Wójcik, M. (2019). In the starting blocks for smart agriculture: The internet as a source of knowledge in transitional agriculture. NJAS-Wageningen Journal of Life Sciences, 90, 100309.

Johnson, T. G., Gautam, S., Mishra, B., \& Haithcoat, T. L. (2011). The Benefits of Expanded Broadband for Missouri Farms and Agribusinesses.

Jouanjean, M.-A. (2019). Digital opportunities for trade in the agriculture and food sectors.

Juswadi, J., Sumarna, P., \& Mulyati, N. S. (2020). Digital Marketing Strategy of Indonesian Agricultural Products. International Conference on Agriculture, Social Sciences, Education, Technology and Health (ICASSETH 2019), $105-110$.

Kingsnorth, S. (2019). Digital marketing strategy: An integrated approach to online marketing. Kogan Page Publishers.

Klerkx, L., Jakku, E., \& Labarthe, P. (2019). A review of social science on digital agriculture, smart farming and agriculture 4.0: New contributions and a future research agenda. NJAS-Wageningen Journal of Life Sciences, 90 , 100315.

Lestari, S., \& Premono, B. T. (2019). Institutional and marketing efficiencies of dragon's blood management in bengkulu province, indonesia. Indonesian Journal of Forestry Research, 6(2), 141-154.

Machfud, A. K., \& Kartiwi, M. (2013). E-commerce adoption by Indonesian small agribusiness: Reconsidering the innovation-decision process model. 2013 5th International Conference on Information and Communication Technology for the Muslim World (ICT4M), 1-6.

Mariyono, J. (2019). Stepping up to market participation of smallholder agriculture in rural areas of Indonesia. Agricultural Finance Review.

Méndez-Lazarte, C.-I. (2019). Dynamic networks in early international agrobusiness.

Molotkova, N. V., Makeeva, M. N., Blium, M. A., Gerasimov, B. I., \& Gerasimova, E. B. (2019). Improving Russian agribusiness competitiveness within the digital transformation framework. International Scientific Conference "Digital Transformation of the Economy: Challenges, Trends, New Opportunities", 342-350.

Naryono, E. (2020). Impact Of National Disaster Covid-19, Indonesia Towards Economic Recession. OSF Preprints.

Oreku, G. S., Mtenzi, F. J., \& Ali, A.-D. (2013). A viewpoint of Tanzania e-commerce and implementation barriers. Computer Science and Information Systems, 10(1), 263-281.

Printezis, I., \& Grebitus, C. (2020). College-Age Millennials' Preferences for Food Supplied by Urban Agriculture. Frontiers in Sustainable Food Systems, 4, 48.

Puchalsky, W., Ribeiro, G. T., da Veiga, C. P., Freire, R. Z., \& dos Santos Coelho, L. (2018). Agribusiness time series forecasting using Wavelet neural networks and metaheuristic optimization: An analysis of the soybean sack price and perishable products demand. International Journal of Production Economics, 203, 174-189. https://doi.org/10.1016/j.ijpe.2018.06.010

Purnomo, N. (2020). Peningkatan Sumber Daya Manusia Melalui Pelatihan Dan Pendampingan Digital Marketing. Jurnal Karya Abdi Masyarakat, 4(3), 376-381. 
Putra, P., Mizani, H., Basir, A., Muflihin, A., \& Aslan, A. (2020). The Relevancy on Education Release Revolution 4.0 in Islamic Basic Education Perspective in Indonesia (An Analysis Study of Paulo Freire's Thought). Test Engineering \& Management, 83, 10256-10263.

Rachmawati, R. R., \& Gunawan, E. (2020). Peranan Petani Milenial mendukung Ekspor Hasil Pertanian di Indonesia. Forum Penelitian Agro Ekonomi, 38(1), 67-87.

Reardon, T., Codron, J. M., Busch, L., Bingen, J., \& Harris, C. (1999). Global change in agrifood grades and standards: agribusiness strategic responses in developing countries. The International Food and Agribusiness Management Review, 2(3-4), 421-435. https://doi.org/10.1016/S1096-7508(01)00035-0

Rambe, P., \& Khaola, P. (2021). The impact of innovation on agribusiness competitiveness: The mediating role of technology transfer and productivity. European Journal of Innovation Management.

Ridha, R. N., \& Wahyu, B. P. (2017). Entrepreneurship intention in agricultural sector of young generation in Indonesia. Asia Pacific Journal of Innovation and Entrepreneurship.

Sanim, B. (2016). Ekonomi Sumber daya Air dan Manajemen Pengembangan Sektor Air Bersih Bagi Kesejahteraan Publik. Pembangunan Dan Kebijakan Ekonomi Indonesia Menghadapi Tantangan Globalisasi Ekonomi, 283.

Silverman, D. (2020). Qualitative research. Sage Publications Limited.

Slamet, A. S., Nakayasu, A., \& Bai, H. (2016). The determinants of organic vegetable purchasing in Jabodetabek region, Indonesia. Foods, 5(4), 85.

Smith, K. T. (2011). Digital marketing strategies that Millennials find appealing, motivating, or just annoying. Journal of Strategic Marketing, 19(6), 489-499.

Sterne, J. (2017). Artificial intelligence for marketing: Practical applications. John Wiley \& Sons.

Sumberg, J., Anyidoho, N. A., Chasukwa, M., Chinsinga, B., Leavy, J., Tadele, G., Whitfield, S., \& Yaro, J. (2014). Young people, agriculture, and employment in rural Africa. African Youth and the Persistence of Marginalization: Employment, Politics, and Prospects for Change, 111-133.

Tsekouropoulos, G., Andreopoulou, Z., Koliouska, C., Koutroumanidis, T., \& Batzios, C. (2013). Internet functions in marketing: Multicriteria ranking of agricultural SMEs websites in Greece. Agrárinformatika/Journal of Agricultural Informatics, 4(2), 22-36.

Utami, D. P. (2020). Pengenalan Digital Marketing dalam Pemasaran Produk Pertanian Untuk Petani Milenial Desa Wonotulus Kecamatan Purworejo Kabupaten Purworejo. Prosiding seminar nasional pertanian, 1(1), 25-32.

Vassiliadou, S., Vogiatzi, M., Amygdalas, T., \& Mpoutakidis, D. (2011). The Use of Social Media Among Students of Technology Agriculture and their Role In Promoting Agribusiness. HAICTA, 203-211.

Wang, S., Tian, Y., Liu, X., \& Foley, M. (2020). How farmers make investment decisions: Evidence from a farmer survey in China. Sustainability, 12(1), 247.

Wulandari, I. G. A. A., \& Parameswara, A. G. A. (2019). Pengaruh Pendapatan per Kapita, Suku Bunga Bi Rate, Inflasi dan Kurs Dollar Amerika Serikat terhadap Simpanan Pihak Ketiga pada Bank Umum di Provinsi Bali. Warmadewa Economic Development Journal (WEDJ), 2(1), 10-17.

Yuendini, E. P., Rachmi, I. N., Aini, N. N., Harini, R., \& Alfana, M. A. F. (2019). Analisis Potensi Ekonomi Sektor Pertanian dan Sektor Pariwisata di Provinsi Bali Menggunakan Teknik Analisis Regional. Jurnal Geografi: Media Informasi Pengembangan Dan Profesi Kegeografian, 16(2), 128-136.

Ziggers, G. W., \& Trienekens, J. (1999). Quality assurance in food and agribusiness supply chains: Developing successful partnerships. International journal of production economics, 60, 271-279. https://doi.org/10.1016/S0925-5273(98)00138-8 